\title{
CAVE FORMS AND ORIGIN OF THE CAVE PEČINA V ZJATIH (MATARSKO PODOLJE, SLOVENIA)
}

\section{JAMSKE OBLIKE IN NASTANEK JAME PEČINA V ZJATIH (MATARSKO PODOLJE, SLOVENIJA)}

\author{
TIMOTEJ VERBOVŠEK ${ }^{1}$
}

${ }^{1}$ Tbilisijska ulica 158, SI-1000 LJUBLJANA, SLOVENIA 
Abstract

UDC 551.44(497.4)

Timotej Verbovšek: Cave forms and origin of the cave Pečina v Zjatih (Matarsko podolje, Slovenia)

Cave lies in Matarsko podolje, in southwestern part of Slovenia. Surrounding beds are composed of limestones and limestone breccias of Cretaceous age. In the vicinity there are many dolines and collapse dolines. The entrance and final part of the cave are situated directly under the big dolines. Because of the small doline, which can be found above the middle part of the cave, there are many flowstone features. Obvious damages due to the freezing and thawing are found along the most part of the cave, at the entrance there is a lot of cryoclastic gravel. Cave began to form in phreatic and later in epiphreatic conditions. Palaeoflow discharge indicates great amount of water.

Key words: cave, Pečina v Zjatih, contact karst, dolines, speleology, Slovenia.

Izvleček

UDK 551.44(497.4)

\section{Timotej Verbovšek: Jamske oblike in nastanek jame Pečina v Zjatih (Matarsko podolje, Slovenija)}

Jama leži v Matarskem podolju, v SZ delu Slovenije. Okolico sestavljajo apnenci ter apnenčaste breče kredne starosti. Njen vhodni del je udornega nastanka in leži v večji vrtači, jama pa se konča s podorom pod drugo vrtačo. Nad osrednjim delom jame je tudi manjša vrtača; posledica je, da je v tem delu obilnejša siga. Očitne so poškodbe zaradi zmrzali, ki segajo globoko v jamo; v vhodnem delu so značilni pojavi plazenja krioklastičnega grušča. Jama je sprva nastajala v freatičnih, nato pa v epifreatičnih pogojih. Izračunan nekdanji pretok kaže na veliko količino vode.

Ključne besede: jama, Pečina v Zjatih, kontaktni kras, vrtače, speleologija, Slovenija. 


\section{INTRODUCTION}

The main part of the research work was done in the early months of 2002 by A. Krapež, N. Sterle and T. Verbovšek, under the supervision of prof. F. Šušteršič. Earlier studies were carried out in 1909 by A.G. Perko (of the Hades Speleological Club, Trieste) and in 1981 and 1983 by the Dimnice Speleological Club from Koper. In 1986 they also produced a map of the cave, while the present map was done by the above-mentioned persons.

\section{GEOGRAPHICAL AND GEOLOGICAL SETTING}

The cave is approximately $250 \mathrm{~m}$ long and $53 \mathrm{~m}$ deep. The entrance has an elevation of 505 meters, its co-ordinates are $\lambda=14^{\circ} 0$ ' $49^{\prime \prime} \mathrm{E}$ and $\varphi=45^{\circ} 33^{\prime} 23^{\prime \prime} \mathrm{N}$. Its registration number is 2708.

It is situated in Matarsko podolje, a significant karst area in southwestern Slovenia, southeast of the Karst (Kras) plateau. It is easily accessible from the regional road between Kozina and Reka.

Structurally, Matarsko podolje is an anticline, composed mostly of Cretaceous carbonates. The anticlinal axis is oriented northwest - southeast. On its northeastern flank are the Brkini hills,

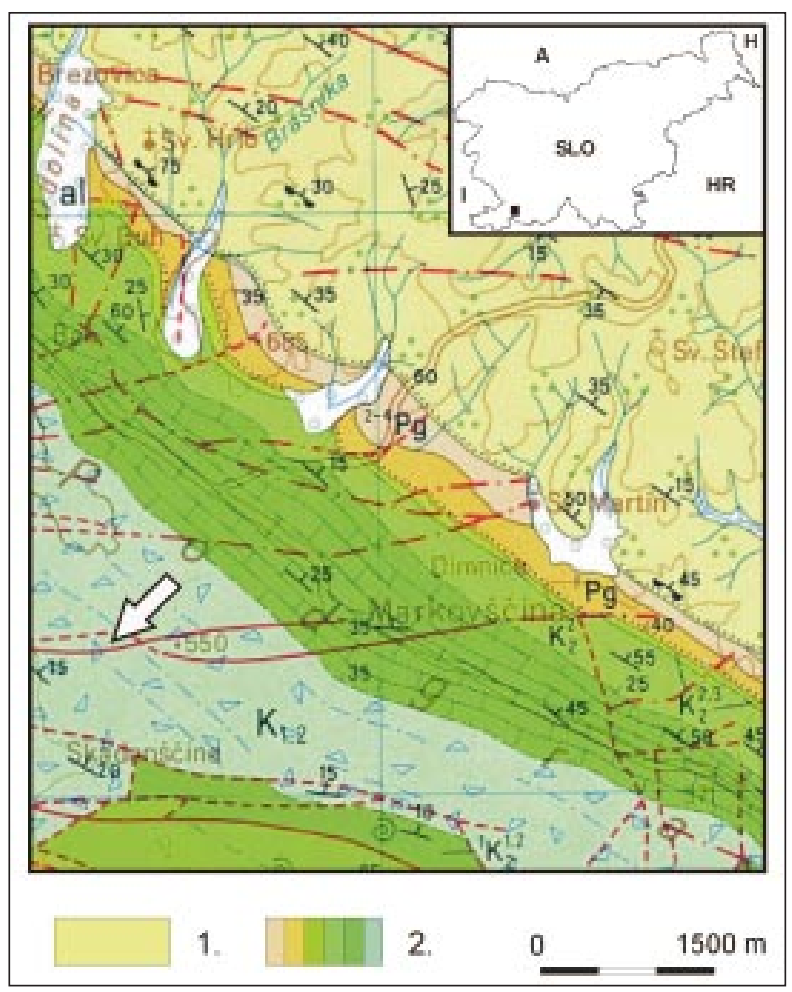
composed of Eocene flysch. The southwestern limb is Čičarija (with its highest elevation at Mt. Slavnik, $1028 \mathrm{~m}$ ), composed dominantly of Cretaceous carbonates. The contact between the carbonates and flysch is generally an erosional unconformity, but tectonic contacts occur in a few places (Fig. 1).

Fig. 1: Geological map of the studied area (Šikič et al., 1967). The arrow marks the position of the cave.

(Legend: 1. Eocene flysch;

2. Cretaceous to Palaeogene Carbonates, mostly limestones.) Sl. 1: Geološka karta obravnavanega območja (Šikič et al., 1967). Puščica označuje lokacijo jame. (Legenda: 1. Eocenski fliš; 2. Kredni in paleogenski karbonati, predvsem apnenci.) 


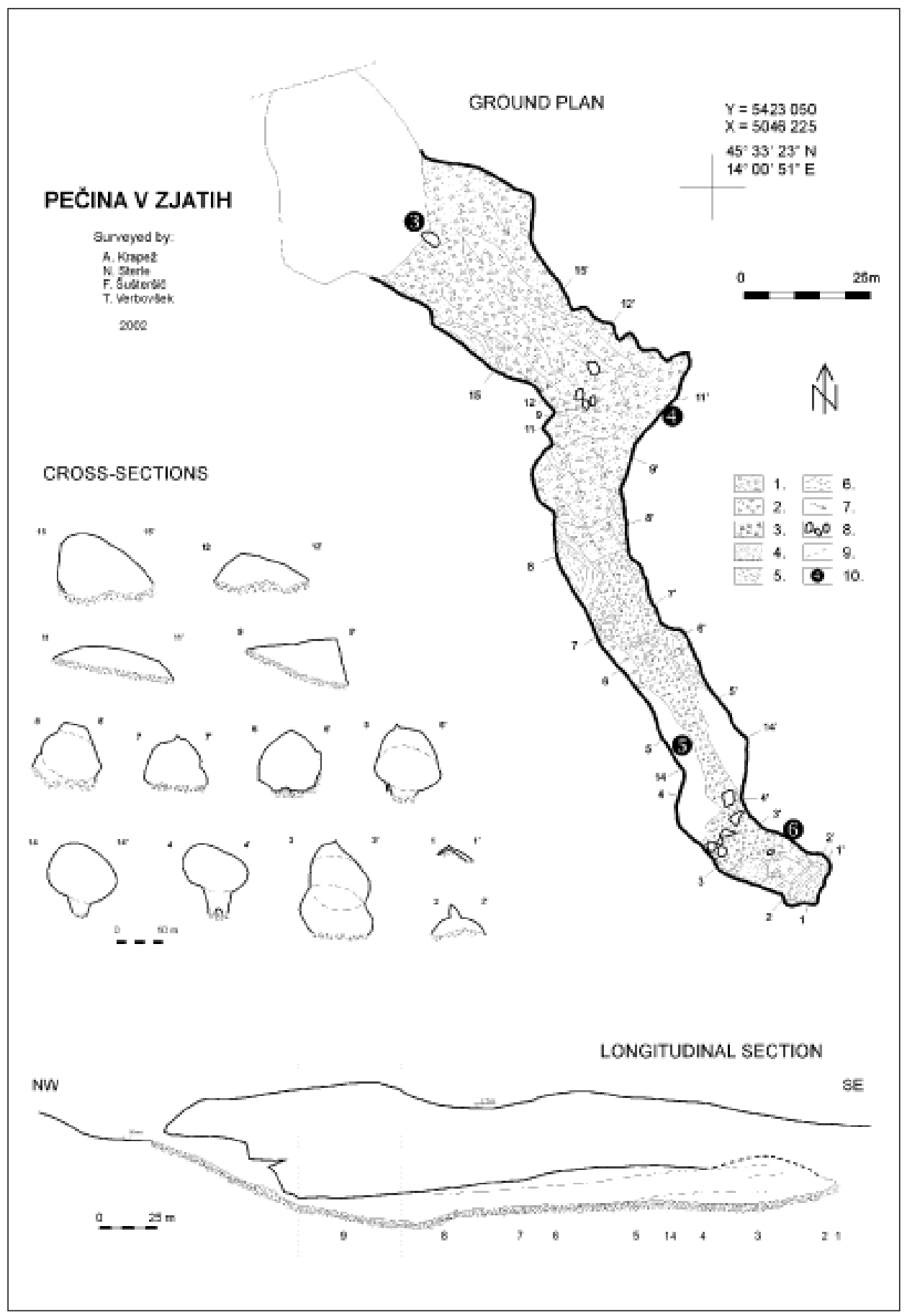


Fig. 2: Ground plan, cross-sections and longitudinal section of Pečina v Zjatih. (Legend: 1. Gravel with clay; 2. Gravel; 3. Flowstone blocks; 4. Clay; 5. Flowstone; 6. Ground flowstone; 7. Direction of dip of the slope; 8. Bigger rocks; 9. Minor fault; 10. Places and numbers of taken photographs.). Dotted lines in longitudinal and cross sections indicate position of reconstructed elliptical phreatic passage. (on page 134)

Sl. 2: Tloris, prečni in vzdolžni profil Pečine v Zjatih. (Legenda: 1. Grušč z glino; 2. Grušč; 3. Bloki sige; 4. Glina; 5. Siga; 6. Talna siga; 7. Smer vpada pobočij; 8. Večje skale; 9. Manjši prelom; 10. Mesta fotografij, številke označujejo št. slik.). Črtkane linije na profilih prikazujejo rekonstruiran elipsast freatični rov. (na strani 134)

Streams flowing from the Brkini hills sink into Cretaceous carbonates and form distinctive blind valleys. Such valleys are enclosed on all sides, with the upper part incised into clastic flysch rocks and the lower part cut through carbonates. The actual ponor caves descend steeply for about $100 \mathrm{~m}$ until they reach the water table (Mihevc, 1994). Further on the caves are epiphreatic, characteristic of contact karst. Pečina v Zjatih is a fragment of such an epiphreatic system, hardly modified by secondary processes.

Pečina v Zjatih has formed in limestone, calcarenite and limestone breccia of Cretaceous age $\left(\mathrm{K}_{1,2}\right)$ which dip gently towards the northeast at approximately 10 to 20 degrees. The dark grey micritic limestones contain small calcite veins, and are rich in fossils, including ostracods and numerous foraminiferans (Globigerina aeguilataralis, Dicyclina sp., Miliolidae, Globigerinidae, Aeolisaccus sp.). As is characteristic of carbonate formations on the Dinaric platform these beds are very pure. The entire formation is not more than $750 \mathrm{~m}$ thick (Šikić \& Pleničar, 1975).

\section{EXPERIENCES CONCERNING CAVE MEASUREMENT}

Measurement was done by using a tripod-mounted miniature Leica laser distance meter. It was used for measuring distances, and could achieve a theoretical accuracy of plus or minus 1 $\mathrm{mm}$, much more accurate than the "classic" measuring tape method. For practical reasons, however, the results were rounded to the nearest $10 \mathrm{~cm}$, to make them comparable with the direction and dip measurements. The great advantage of this method is that inaccessible points can be measured directly, rather than being calculated from directional measurements from two stations.

Initially, dip angle readings were taken using a compass with a floating pointer (SUUNTO). When reading inclinometer angles, low temperatures $\left(-15^{\circ} \mathrm{C}\right.$ in January) caused the viscosity of the damping fluid to increase, so that the readings became quite inaccurate. This problem was solved by using a Brunton compass, attached to the frame of the laser distance meter.

A GPS (satellite navigation) device with horizontal accuracy of about $3 \mathrm{~m}$ was used to position the cave on the map. The precise location of the cave was also determined by mapping the lowest positions of nearby dolines, which were marked on the 1:5000 map, and thus directly referred to the national grid system (Gauss-Krueger). 


\section{CAVE MORPHOLOGY}

The cave can be divided into two sections - an inclined entrance part and a horizontal part (central and south sections). The most interesting features are found at the bottom of the entrance part, where the cave changes direction from northwest - southeast to northeast - southwest, and in the southern part. Some primary features, suitable for the study of cave genesis, are still preserved.

The cave entrance is within the southern wall of an elliptical collapse doline, with an east to west diameter of $30 \mathrm{~m}$ and north to south diameter of $40 \mathrm{~m}$. The doline has steep slopes and its northern margin is a small vertical fault trending southwest - northeast.

The entrance part of the cave (Fig. 3) is about $60 \mathrm{~m}$ long and $25 \mathrm{~m}$ wide and also of collapse origin, formed by massive ceiling breakdown. The bottom of the entrance section dips steeply towards the southeast and is covered by cryoclastic gravel. A still active secondary process involves heave of gravel particles, which occurs every winter due to freezing and thawing. In this section there are very few primary features, due to the effects of frost shattering and ceiling breakdown. Frost processes have destroyed most of the flowstone, but remnants are still visible

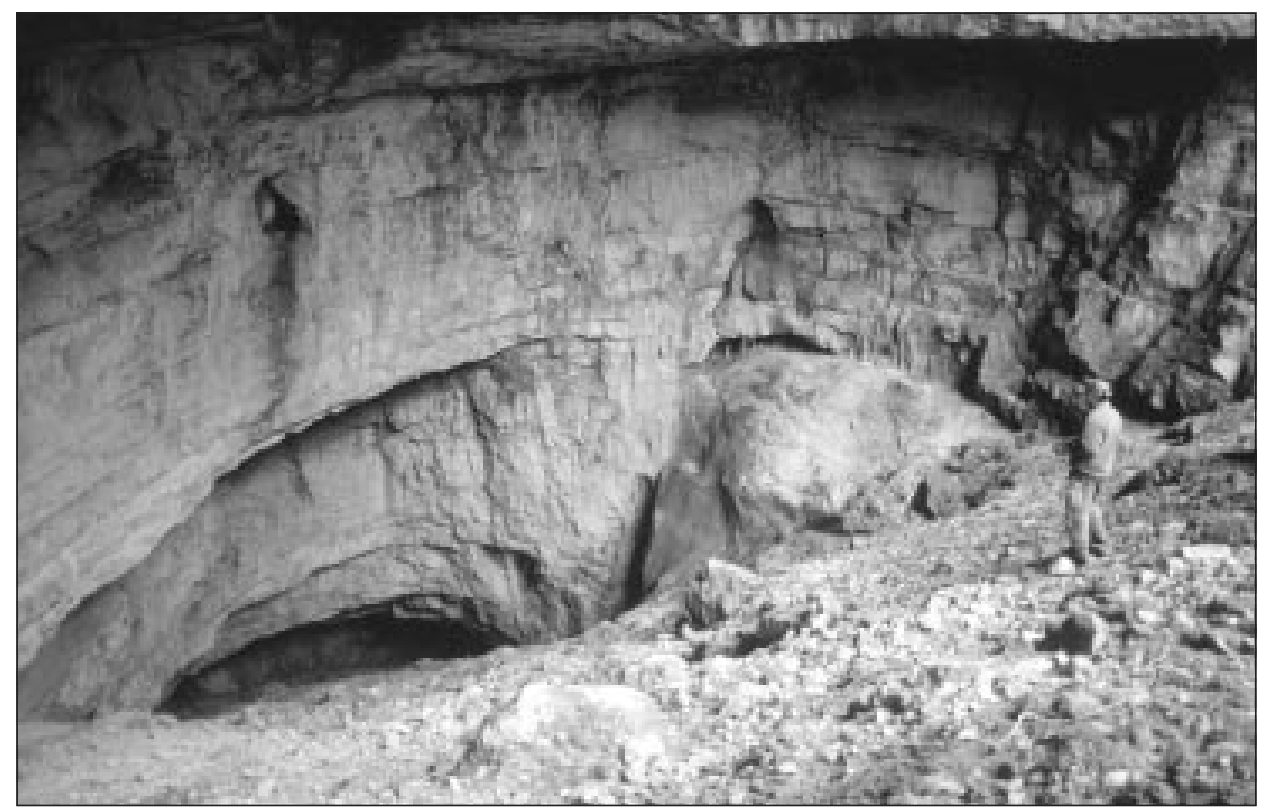

Fig. 3: The entrance section. An inception horizon is visible in the central part. Water flowing out of this produced a big mass of flowstone (on the right). Rubble formed by breakdown of the ceiling. (All photographs by T. Verbovšek).

Sl. 3: Vhodni del. V osrednjem delu je viden začetni horizont. Voda, ki je tekla iz njega, je ustvarila večjo kopo sige (na desni). Grušč je nastal z rušenjem stropnih blokov. (Vse fotografije T. Verbovšek). 
on the walls. Some scallops were found on the eastern wall, but they were too damaged to permit the flow direction to be distinguished. A large mass of flowstone on the west wall, about $15 \mathrm{~m}$ from the entrance, formed when precipitation water, intercepted by the inception horizon visible on the ceiling of the entrance section, poured into the cave. In the northeastern section there are some ceiling pockets, from 10 to $30 \mathrm{~cm}$ in diameter. They are of simple and composite types, indicating turbulent flow. At the time of the research work there were many ice stalagmites growing on the slopes, due to water dripping from the fractured ceiling. A layer of carbonate silt, a few millimetres thick, covers some parts of the walls near the entrance. Its origin has not been studied, but it appears that it contains mostly weathered rock. It was probably deposited by evaporation of condensation water, after the corrosive water had dissolved the cave walls.

In a side room off the main passage a minor intraformational slide of the limestone beds along one of the inception horizons occured (Fig. 4) (Lowe \& Gunn, 1997). Although not visible in the figure, there are many channels developed along this bedding plane. After the primary channel about $10 \mathrm{~cm}$ wide and somewhat less high has been formed, the upper block slid about $3 \mathrm{~cm}$ relative to the basement. As such a displacement would very likely result in massive collapse of the nearby chamber, one can conclude that sliding took place before the initial phreatic system had evolved from the maze of interconnected proto-channels into one or two master tubes.

The lowest part of the cave (cross section number 8), being more enlarged in horizontal and vertical sections, is $14 \mathrm{~m}$ high and $16 \mathrm{~m}$ wide. Here the entrance slope is composed mostly of

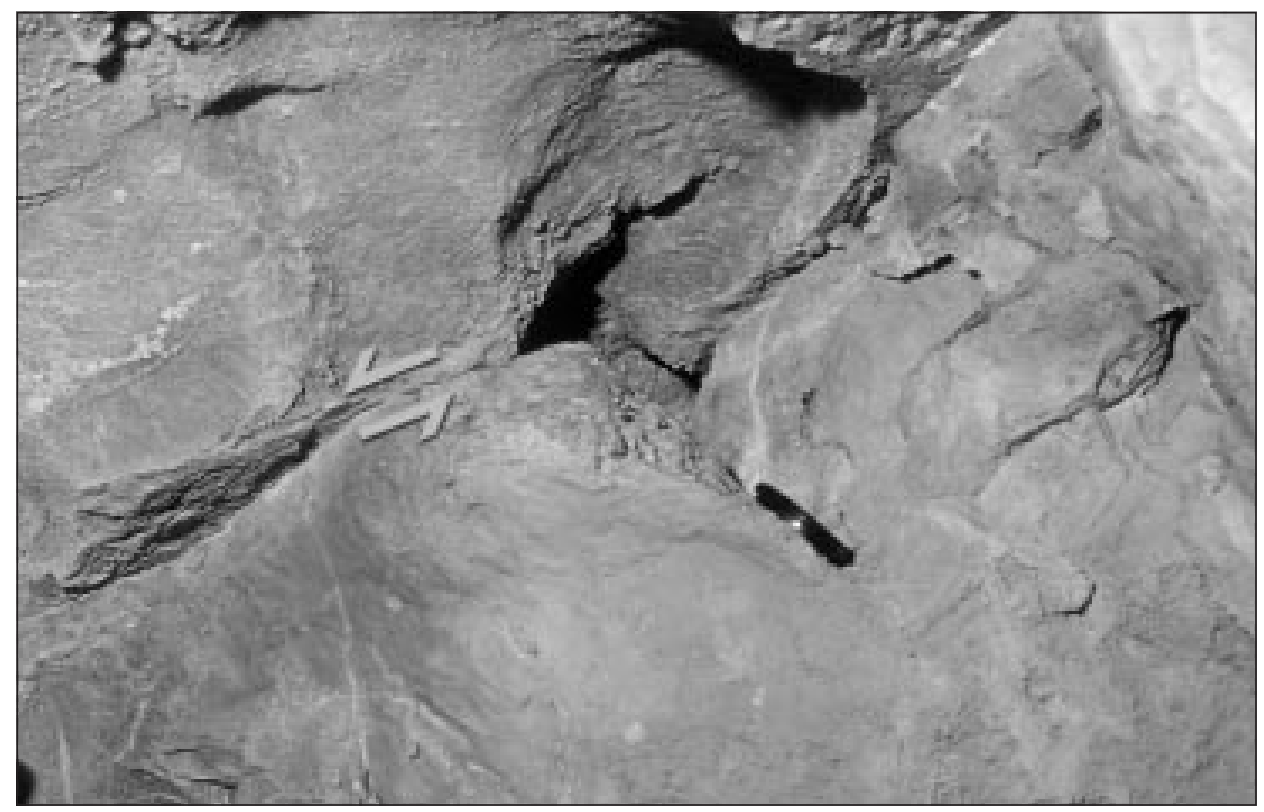

Fig. 4: Small channel developed along the inception horizon. The upper block moved about $3 \mathrm{~cm}$ relatively towards the left.

Sl. 4: Manjši kanal, razvit ob začetnem horizontu. Zgornji blok se je glede na spodnjega premaknil na levo okoli $3 \mathrm{~cm}$. 
cryoclastic rubble with some clay. The floor rises again to the south, and comprises fewer rubble clasts and more clay. Some primary wall features have been preserved, too. Quite circular shape in horizontal section and change in floor elevation indicate that this could be the location of a phreatic jump, not just an enlargement of the passage. Further study is prevented by the floor being buried under gravel, and the ceiling and walls being damaged by frost shattering.

The central section (between cross-sections 6 and 8) has the most flowstone forms. Besides some smaller stalagmites, there is a large mass of flowstone near the western wall at the top of the slope. Its lower part is made up of onion-like layers of flowstone about 10-20 cm thick. Such an exfoliation is characteristic for freezing. Later, water occasionally flowed out of a fissure or crack in the wall, thus separating the layers, which partly slid slowly down the slope. Some blockfall from the ceiling occurred, probably when the cave was flooded, because the wall surfaces are smooth. The origin of the flowstone features can be related to a smaller doline, which lies on the surface exactly above this section of the cave (Fig. 7). Some parts of the flowstone are also very dark in colour, stained red to brown, indicating that the water brings organic material and iron plus manganese oxides from the surface.

In the southern section, the cave passage displays a keyhole-shaped cross-section (Fig. 5, numbers 4, 5 and 14). The upper part is elliptical and the lower part is canyon-like. The elliptical part formed under phreatic flow conditions, when pure water, free of mechanical load, was exca-

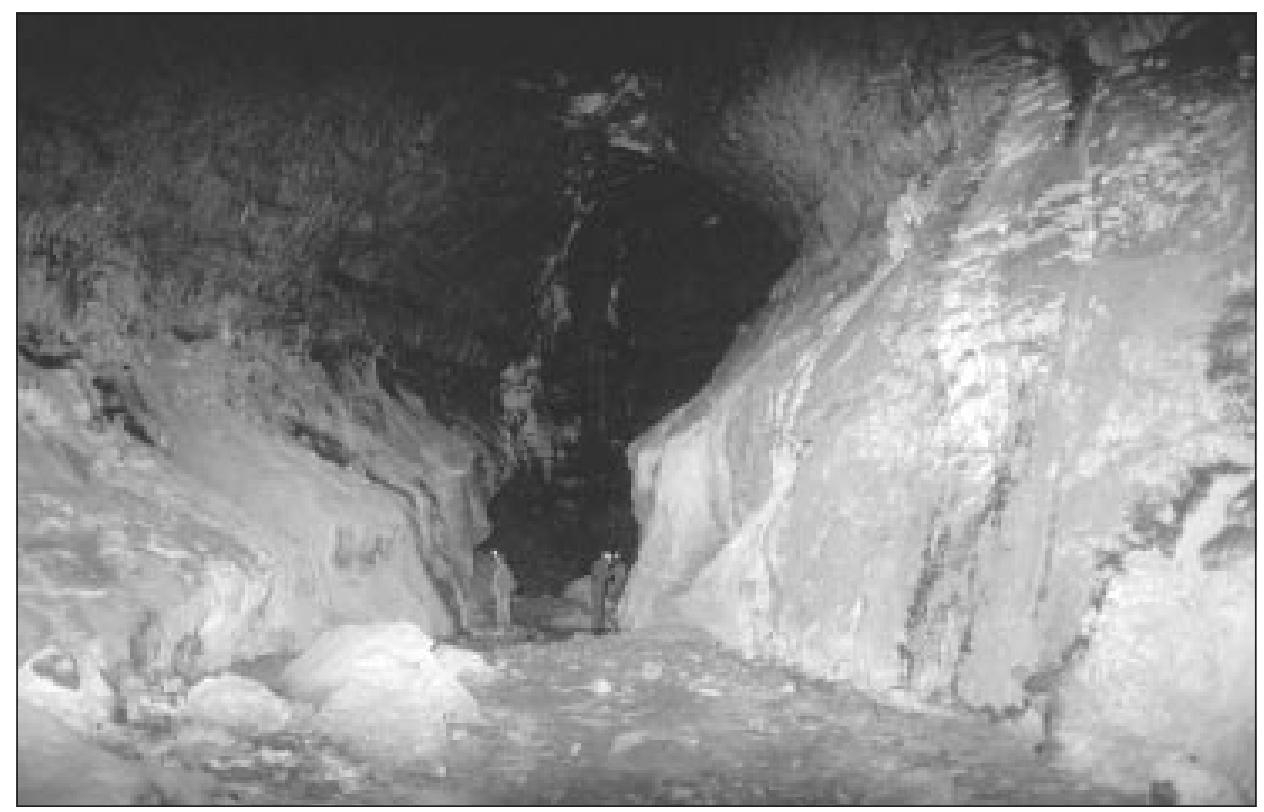

Fig. 5: Keyhole form of the passage. Upper part is elliptical, formed in phreatic condition. Lower part is younger and incised by gravel.

Sl. 5: Rov v obliki ključavnice. Zgornji del je elipsaste oblike in je nastal v freatičnih pogojih. Spodnji del je mlajšega nastanka in je bil vrezan z abrazivnim materialom v epifreatičnih pogojih. 
vating the channel along the inception horizon. Water incised the canyon part later, most likely by abrasion with mechanical load or by corrosion, as explained in the following chapter. As the elliptical passage is parallel to the guiding bedding plane it passes beneath gravel deposits in its northern part (dotted lines in longitudinal section).

There are many rills on the canyon walls, those on the western wall being bigger and better developed than the ones on the eastern side. As they occur on both sides of the canyon, these could not have formed only by water flowing out of the inclined bedding plane, which dips to the northeast. They were probably made by water condensing from moist air and then moving down the walls. However, the process of water flowing out of the bedding plane on the western side could not be excluded due to difference in size of western and eastern rills. Although far from the entrance, the western wall of the canyon is heavily frost damaged. The same process could have widened an obvious relaxation crack, about $15 \mathrm{~cm}$ wide, that runs parallel to the wall.

The largest concentration of preserved scallops is found in this area (Fig. 6). They are big, ranging from about 20 to $30 \mathrm{~cm}$ long, indicating development by slowly running water. Because of their size and injuries by condensation water, the flow direction could not be determined.

This is the location of another phreatic jump, which is evident on cross-section number 3. Water flowing in the lower channel, jumped to a higher one (or vice versa). The ceiling is dome-like and appears to be stable. It is possible that there is another active channel beneath this sec-

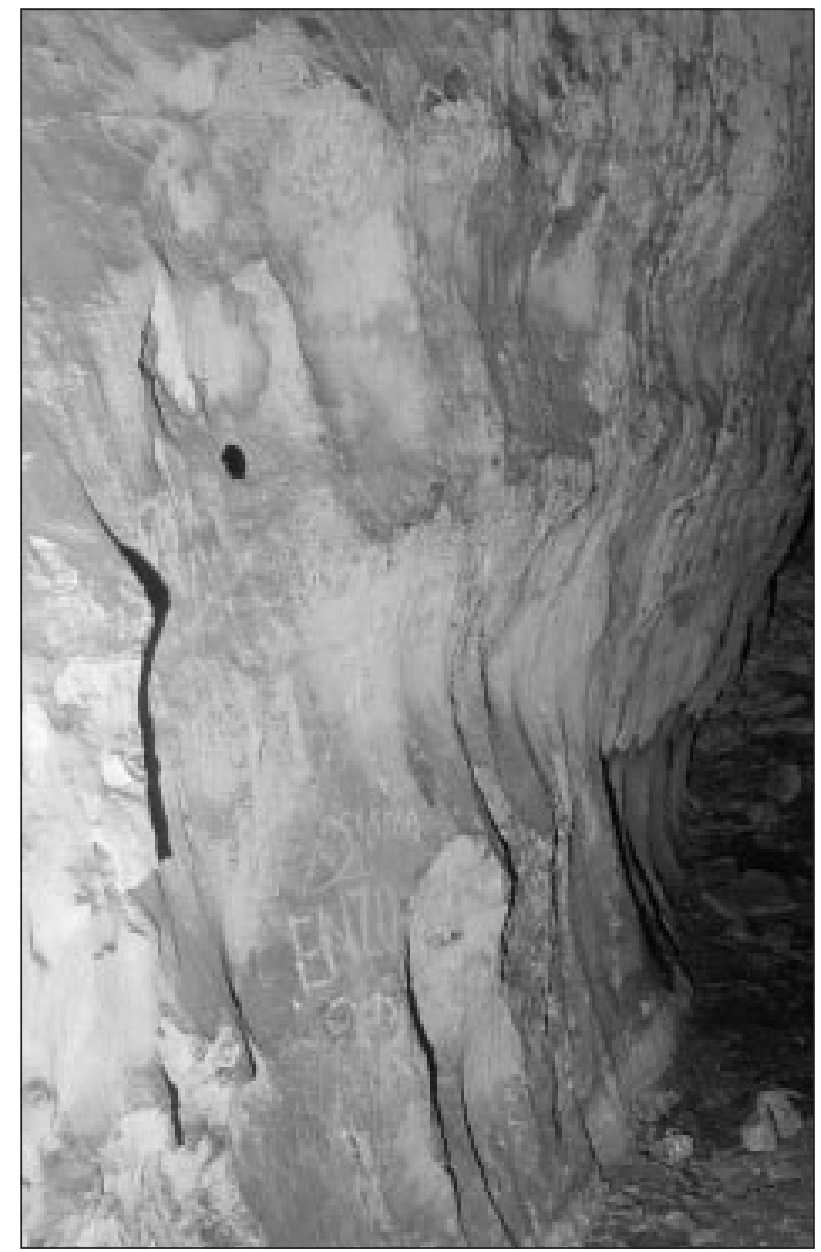

Fig. 6: Bigger scallops. These are the best preserved, while most are heavily damaged by frost and aggressive condensation water.

Sl. 6: Večje fasete. Te so najbolje ohranjene, ostale so namreč močno poškodovane zaradi zmrzali in kondenzne vode. 
tion, as the funnel-like depression in the sedimentary floor appears quite fresh.

The cave is terminated by breakdown material, composed of cryoclastic rubble and clay (crosssections 1, 2 and 3), with its upper part covered in flowstone. From the topographic map (Fig. 7), it is clear that there is a bigger doline above, about 50 metres in diameter. This is probably a doline of collapse origin, but its bottom was recently levelled anthropogenically, so its morphology and, consequently, its genesis could not be investigated.

\section{CAVE GENESIS}

Though rather obscured by recent intensive processes, the cave features reflect hydraulic and climate conditions from the beginning of its genesis up to the present. The cave began to form under phreatic conditions, with the first passages developing along two or three inception horizons. Water made two phreatic jumps, switching between inception horizons on the locations of enlargements in the final and probably also lowest part of the cave. At the same time, while these passages grew larger, scallops and ceiling pockets also developed. Estimated flow speed $v=16 \mathrm{~cm} / \mathrm{s}$, determined from the diagram by Ford \& Williams (1989, 305-306). The approximate area of the reconstructed ellipse is $A=119 \mathrm{~m}^{2}$. Considering the flow velocity, the discharge can be calculated as being $Q=A v=19 \mathrm{~m}^{3} / \mathrm{s}$. Values of velocities plus discharges are only approximate and can be found in the $\pm 30 \%$ range.

Entrenchment began when cave development conditions switched from phreatic to epiphreatic. Most likely allochtonous material acted as an abrasive to deepen the trench. Water tracing tests have shown that streams sinking into the nearby blind valleys in northern and central part of Brkini hills drain to the southwest and appear in the spring of Rižana river. More distant streams from the southern part of Brkini hills appear in the Adriatic sea near Opatija in Croatia (Novak, 1990). If we presume that hydrological conditions during the entrenchment were similar to the present ones, the abrasive material that caused entrenchment is certainly flysch gravel from the Brkini hills. Large amounts of flysch pebbles are found in the nearby cave Medvedjak (Fig. 7) and one can hardly expect that similar material would be completely absent in Pečina v Zjatih. Seeming lack of fluvial material in studied cave is explained by thick cover of weathered material, decayed flowstone and loam washed from the surface. Most probably the entrenchment took place in Pleistocene, when there was the biggest production of rubble due to cold climate and consequently thin or even absent vegetation cover.

Another explanation for entrenchment would be that the canyon part was incised by corrosive water. This process might be involved in the first phases of entrenchment, after the discharge had dropped significantly. If only this process had been involved, at least remnants of corrosive incisions would be present on the walls in the former water table elevation. However, they are completely absent. Thus, it is more probable that incision took place with abrasive material, for the reasons alreadly mentioned.

Water probably withdrew into deeper levels a long time ago. Denudation reduced the thickness of the cave roof to such an extent that the ceiling became unstable and the entrance collapse doline formed. The genesis of the doline above the end part could be similar to that of the entrance doline, except that the underlying cavern was smaller and deeper.

Reshaping of the cave began when it became exposed to surface-related climatic factors that 


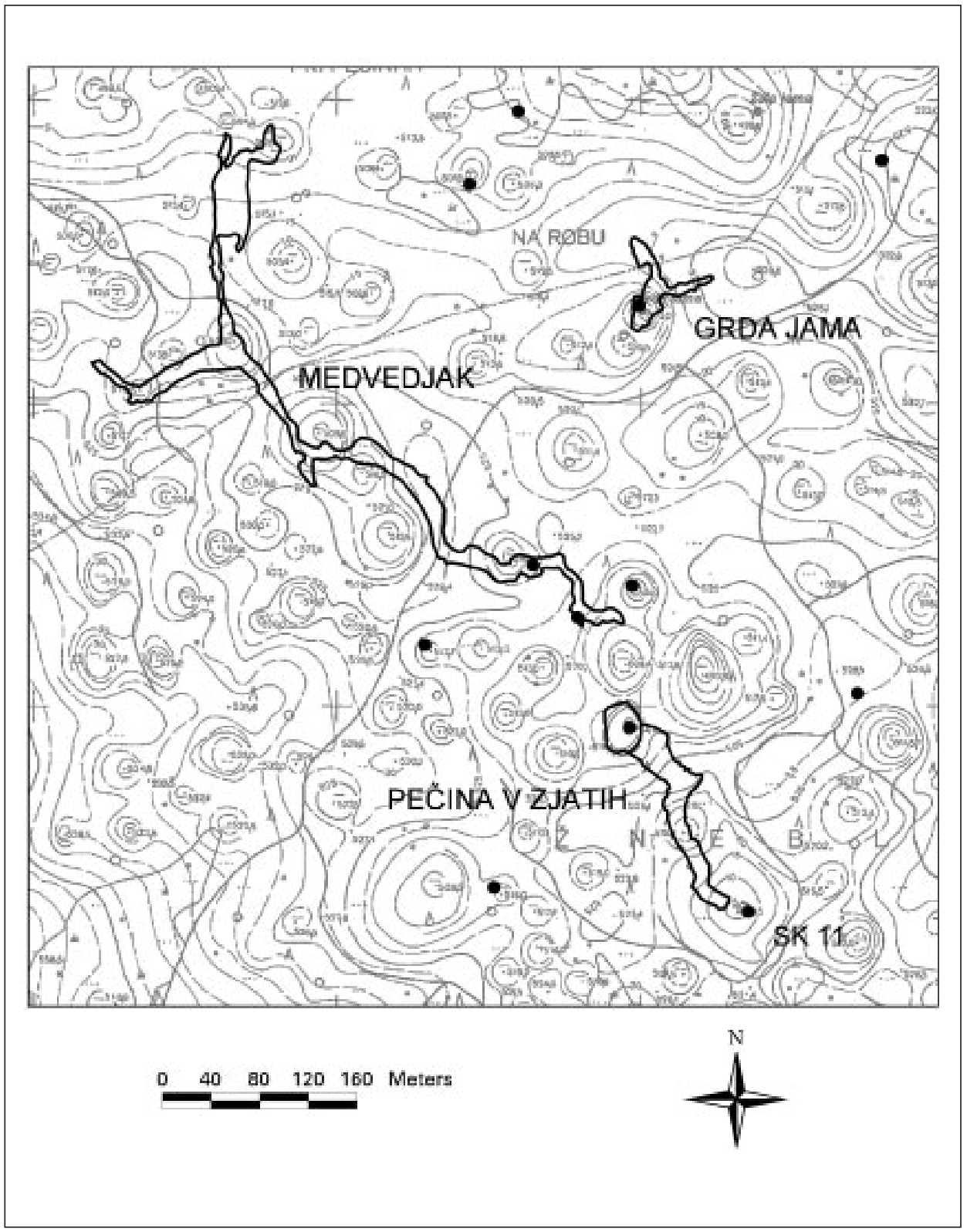

Fig. 7: Extract from the 1:5000 topographical map with entrances marked and ground plans of the biggest caves in the vicinity of Pečina $v$ Zjatih.

Sl. 7: Izsek iz temeljnega topografskega načrta z vrisanimi vhodi ter tlorisi večjih jam v okolici Pečine v Zjatih.

Vir: Temeljni topografski načrt merila 1:5000. (C) Geodetska uprava Republike Slovenije, 1981 
allowed secondary processes to begin. Frost damage and corrosion have changed the primary features of the walls and ceiling by destroying scallops and other wall formations. Block breakdown of the ceiling in the entrance partly buried the primary passage, so it is impossible to determine its continuation towards the north. One possibility is that it trends in a northeast direction towards a deep doline, with steep slopes that could indicate collapse origin.

From the map (Fig. 7) it is evident that the cave is part of a bigger cave system. In the vicinity of Pečina v Zjatih are a number of caves, of which Medvedjak is the biggest. One can assume that Pečina v Zjatih and Medvedjak belong to the same system. However, little is known about the primary processes that led to the formation of the bigger phreatic passages. Considering the estimated discharge of the load-free water that had excavated the upper (elliptical) part of the large keyhole type passage in Pečina $v$ Zjatih, it could not possibly have originated from the highly pebble loaded streamlets from the Brkini hills. The calculated discharge of the cave is much more than the total discharge from the entire area. 17 streams from the southern side of Brkini hills drain about $29.2 \mathrm{~km}^{2}$ of the flysch area. Stream Brsnica, for example, drains $4.3 \mathrm{~km}^{2}$ with a discharge of $0.015 \mathrm{~m}^{3} / \mathrm{s}$ (Mihevc, 1994). Large discharge and the lack of the mechanical load during the initial phase testify that the early cave was formed by autochtonous karst water, originating from some more distant area. Flysch-loaded water, which entrenched the relatively narrow canyon-like part of the passage, may have appeared much later, when the hydrological conditions became similar to the present ones. It is likely that much of the abrasive material formed in cold periods of Pleistocene, when there was bigger production of clastic material.

\section{ACKNOWLEDGMENTS}

The author would like to thank prof. dr. France Šušteršič for many useful suggestions and Dr. David J. Lowe for smoothing the text.

\section{REFERENCES}

Ford, D.C. \& Williams, P.W., 1989: Karst geomorphology and hydrology.- Chapman \& Hall, p. 601, London.

Lowe, D. \& Gunn, J., 1997: Carbonate speleogenesis: an inception horizon hypothesis (Speleogeneza v karbonatnih kamninah: hipoteza začetnih horizontov).- Acta Carsologica XXVI/2 (1997), Ljubljana, 457-488

Mihevc, A., 1994: Brkinski kontaktni kras.- Acta Carsologica XXIII (1994), Ljubljana, 99-109

Novak, D., 1990: Novejša sledenja kraških voda v Sloveniji po letu 1965.- Geologija 33, Ljubljana, 461-478

Šikić, D. \& Pleničar, M., 1975: Osnovna geološka karta SFRJ. 1:100000. Tolmač lista Ilirska Bistrica L 33-89.- Zvezni geološki zavod, Beograd, 15-17

Šikić, D., Pleničar, M., Šparica, M., 1967: Osnovna geološka karta SFRJ. L 33-89, Ilirska Bistrica. 1:100000.- Zvezni geološki zavod, Beograd.

Urankar, R., Šušteršič, F., Simić, M., Praprotnik, A., 2001: Ne hodi v jame brez glave.- Društvo za raziskovanje jam, 131 str., Ljubljana. 


\section{JAMSKE OBLIKE IN NASTANEK JAME PEČINA V ZJATIH (MATARSKO PODOLJE, SLOVENIJA)}

\section{Povzetek}

Jama Pečina v Zjatih leži v krednih apnencih in apnenčastih brečah Matarskega podolja, ki vpadajo proti severovzhodu pod flišne plasti Brkinskega hribovja (Sl. 1). Razdelimo jo lahko na dva dela - poševnega vhodnega ter horizontalnega osrednjega in južnega dela.

Vhod se nahaja v udorni vrtači premera 30 do 40 m. Vhodni del (Sl. 3) je zaradi izpostavljenosti zunanjim klimatskih pogojem zelo preoblikovan zaradi zmrzali, zato v tem delu ni veliko primarnih jamskih oblik. Pobočje je prekrito s krioklastičnim gruščem, ki nastaja z rušenjem stropnih blokov. Grušč se s krioturbacijo (pednjanjem) pomika proti osrednjemu delu jame. Redke ohranjene primarne oblike so stropne kotlice in večje fasete. Na steni na dnu vhodnega dela je opazen manjši medplastovni zdrs ob začetnem horizontu (S1. 4). Premik se je verjetno zgodil v začetni fazi nastajanja manjših prepletenih kanalov, ko ti še niso bili povezani v večje rove, ki bi se ob tako velikem premiku verjetno zrušili. V osrednjem delu je največ speleotemov - stalagmitov, talne sige in velike sigaste kope. Njihov nastanek je očitno povezan z vrtačo manjših dimenzij, ki leži natanko nad tem delom. V južnem delu ima profil rova obliko ključavnice (Sl. 5). Zgornji, elipsasti del je starejši in je nastal v freatičnih pogojih ob začetnem horizontu. Spodnji, kanjonski del pa je mlajši, nastal najverjetneje $\mathrm{z}$ vrezovanjem struge $\mathrm{z}$ abrazivnim materialom. Kanjon bi lahko vrezala tudi korozivna voda, ko se je pretok v jami precej zmanjšal. Bolj verjetna pa je prva razlaga, saj dobimo v bližnji jami Medvedjak velike količine flišnega proda, ki je $\mathrm{v}$ Pečini $\mathrm{v}$ Zjatih najverjetneje prekrit s plastjo preperine. Tudi $v$ srednjih in končnih delih so še očitne poškodbe zaradi zmrzali. Jama se konča s gruščnatim podorom pod večjo vrtačo. V tem delu je opazen freatični skok, vodni tok je preskočil iz enega začetnega horizonta v drugega. Tu najdemo edine dobro ohranjene fasete (Sl. 6), dolge od 20 do $30 \mathrm{~cm}$, s pomočjo katerih je bila izračunana hitrost toka.

Jama je sprva nastajala $v$ freatičnih pogojih, $v$ tem času so nastale stropne kotlice in fasete. Izračunana hitrost nekdanjega vodnega toka je $v=16 \mathrm{~cm} / \mathrm{s}$ (Ford \& Williams, 1989), povprečna ploščina prereza rekonstruiranega elipsastega rova pa $A=119 \mathrm{~m}^{2}$. Ocenjeni pretok skozi jamo je torej $Q=A v=19 \mathrm{~m}^{3} / \mathrm{s}$. Ko je voda začela nositi alohton material, je z njim vrezala kanjonski del ključavnice. To se je dogajalo v epifreatičnih pogojih. Sestave abraziva se ni dalo ugotoviti, ker so tla $\mathrm{v}$ tem delu prekrita $\mathrm{z}$ glino ter $\mathrm{z}$ redkimi kosi karbonatnega grušča.

Kasneje se je voda umaknila v nižje predele, saj je jama danes suha. Denudacija je medtem toliko znižala površje, da se je udrla vhodna vrtača. Takrat so začeli jamo preoblikovati zunanji klimatski faktorji, predvsem zmrzal in korozija, ki so uničili večino primarnih oblik. Material, nastal z zrušenjem stropa, preprečuje raziskovanje nadaljevanja jame, vendar je iz karte (Sl. 7) očitno, da pripada Pečina v Zjatih večjemu jamskemu sistemu, katerega del je tudi Medvedjak. Če predpostavimo, da naj bi voda $\mathrm{z}$ abrazivom tekla v približno isti smeri kot danes, iz Brkinov proti Rižani ali Kvarnerskemu zalivu (Novak, 1990), potem lahko sklepamo, da je abraziv prihajal iz Brkinov in je bil torej flišne sestave. Manj pa je znanega o prvotnih procesih nastanka jame. Izračunani pretok je namreč nekajkrat večji od skupnega pretoka današnjih vod na širšem območju. Poleg tega v začetnih freatičnih pogojih voda s seboj ni nosila abraziva, kar tudi kaže, da so bili 
hidrološki pogoji v času nastanka jame dokaj različni od današnjih. Voda je bila izključno kraška. Vrezovanje kanjona z abrazivnim, verjetno flišnim materialom, pa je potekalo dosti pozneje, ko so postale hidrološke razmere že podobne današnjim. Najverjetneje je vrezovanje potekalo $\mathrm{v}$ pleistocenu, ko je bila največja produkcija grušča zaradi hladne klime in posledično stanjšanega vegetacijskega pokrova.

* The dimensions of measured scallops range between $20 \mathrm{~cm}$ and $30 \mathrm{~cm}$. So, velocities range between $13 \mathrm{~cm} / \mathrm{s}$ and $21 \mathrm{~cm} / \mathrm{s}$, while discharges range between $15 \mathrm{~m}^{3} / \mathrm{s}$ and $25 \mathrm{~m}^{3} / \mathrm{s}$. The figures given in the main text were calculated from the mean scallop lenght. 